\title{
SILVA, D. E. G. (ORG.) LÍNGUA, GRAMÁTICA E DISCURSO. GOIÂNIA: CÂNONE EDITORIAL/ GRUPO DE ESTUDOS DE LINGUAGEM DO CENTRO-OESTE, 2006.
}

\section{Resenhado por: Carmem Cecília Camatari Galvão de Menezes}

Denize Elena Garcia da Silva, doutora em Lingüística Hispânica, professora da Universidade de Brasília (UnB) e fundadora do Grupo de Estudos de Linguagem do Centro-Oeste (GELCO), traz ao grande público 14 artigos selecionados entre os cerca de 600 trabalhos discutidos no II GELCO, realizado na Universidade Federal de Goiás (UFG), em outubro de 2002. Língua, gramática e discurso envolve 4 partes - todas nomeadas no campo semântico de caminho e percurso - que enfocam braços teóricos dos estudos lingüísticos que não se pode mais tratar como opostos e excludentes. Como Marcuschi afirma no Prefácio, "os autores aqui lançados, tanto pela seriedade das abordagens como pela harmoniosa convivência teórica que apenas enriquece e mostra como o diálogo é produtivo e, por isso mesmo, cada vez mais urgente" (p. 11). Daí vem a primeira importância desta obra: agregar estudos de línguas indígenas, de gramática gerativa e de análise de discurso crítica em um único volume. A segunda importância é a homenagem à "professora e pesquisadora exemplar, Lúcia Maria Pinheiro Lobato [...] falecida em 30 de novembro de 2005" (p. 9), "em sinal de respeito, carinho e reverência por sua dedicação ao ensino e à pesquisa lingüística no Brasil e pela qualidade excepcional de seu trabalho" (p. 9) nas palavras do prefaciador.

A "1.a Parte - Caminhos da Linguiística" traz 5 artigos de pesquisadoras renomadas, entre elas a homenageada por esta coletânea. São artigos que focalizam a ciência lingüística em suas várias possibilidades interpretativas.

Em "Lingüística Textual hoje: questões e perspectivas", Ingedore G. Villaça Koch mostra as diferentes concepções de texto na evolução da lingüística textual (LT) e verifica se esta tornou-se ciência integrativa de várias outras e uma ciência da linguagem. Conclui afirmando que a LT tornou-se entroncamento e ponto de partida de vários caminhos em várias direções de todas as áreas que têm como sujeito central o ser humano.

Em "Línguas indígenas ameaçadas: documentação, tipologias sociolingüísticas e educação escolar", Silvia Lucia Bigonjal Braggio expõe motivos políticos, econômicos e ideológicos que estão levando à extinção línguas indígenas, seja pelo desaparecimetno do povo, da política assimilacionista/ 
integracionista ou pela mudança no ecossistema. E propõe como tarefa da lingüística a análise e a descrição dessas línguas, o estudo da situação sociolingüística, a educação escolar bilíngüe.

Em seu artigo, intitulado "Sobre a questão da influência ameríndia na formação do português do Brasil", a grande homenageada Lúcia Maria Pinheiro Lobato tem, por objetivo, trazer a questão da possível influência de línguas indígenas ou gerais na formação do português do Brasil (PB), sob a hipótese de que a aprendizagem do português se deu como segunda língua, na idade adulta, o que levaria a pontos de convergência entre o português contemporâneo do Brasil e o tupi e a língua geral paulista.

No quarto artigo, "As categorias lexicais, os predicados e a expressão dos fenômenos meteorológicos em guarani antigo", pesquisadora da UnB Daniele Marcelle Grannier estuda aspectos morfossintáticos do guarani antigo, uma língua polissintética, em que se grupam, no vocábulo, 4 elementos lexicais. Quanto aos predicados, identifica 4 tipos: verbais transitivos, verbais intransitivos, nominais possuíveis e nominais não-possuíveis. Em se tratando de processos, explicita 2: incorporação de objetos e incorporação de sujeito, sempre com o propósito de destacar características dessa língua falada no século XVII e no XVII.

Em "O olhar da Análise de Discurso Crítica sobre as identidades no ensino/aprendizagem do português", a professora da UnB Maria Christina Diniz Leal visa a expor contribuições da análise de discurso crítica na análise da identidade no processo de ensino/aprendizagem de língua portuguesa, tanto do professor quanto do aluno. Afirma ela que, mediante certas práticas, como a obediência ao currículo e a desvalorização do conhecimento prévio do aluno, o professor está sendo coisificado e proletarizado.

$\mathrm{Na}$ "2 a Parte - Nos passos da sintaxe gerativa", agrupam-se 3 artigos escritos sob a luz teórica chomskyana, sendo 2 pesquisadoras renomadas e 1 de pesquisador da nova, produtiva e competente geração de lingüistas. São textos que enfocam diacronia e mudança lingüística e sincronia em estudo de caso.

Abrindo esta parte, "Aspectos diacrônicos do sistema pronominal no português brasileiro", da professora da Universidade de São Paulo (USP) Maria Aparecida C. R. Torres Morais tem-se o foco direcionado para a sintaxe dos clíticos no português do Brasil, considerado um diassistema, definido pela polaridade que se observa nos usos cultos e usos vernáculos atuais. A autora aborda a mudança na expressão do dativo que se tornou atribuído por categoria funcional e associado a papéis temáticos específicos.

No próximo artigo, "Diversidade e mudança lingüística na perspectiva da Gramática Gerativa”, a pesquisadora da UnB Heloísa Maria M. Lima-Sal- 
les discute diversidade e mudança lingüística e traça histórico dos estudos sobre esse tema, com o objetivo de apresentar alguns aspectos que fundamentam a investigação de mudança, ainda por se realizar.

Em "Partição de constituintes no português brasileiro: características sintáticas", ainda no campo teórico do minimalismo, o professor mestre Marcus Vinicius da Silva Lunguinho aborda o fenômeno sintático da partição de constituintes e busca responder a 2 perguntas: como são licenciados os elementos nominais? e como são derivadas as sentenças? A resposta à primeira pergunta envolve o alçamento do possuidor e a resposta à segunda trata de numerações distintas entre estruturas com partição e sem partição sintática.

A "3ㄹ Parte - Nos passos da análise do discurso crítica" volta seu olhar a estudos desenvolvidos sob a influência teórica da análise de discurso faircloughhiana e abarca 3 artigos, sendo o primeiro de outra grande promessa da moderna lingüística brasileira os próximos 2 de pesquisadoras consagradas.

Em "Arqueologia da formação do professor de português: das práticas de letramento às formações discursivas", o doutorando na Universidade de Campinas (Unicamp) Alexandre Costa procura explicar a arqueologia da formação do professor e as formações discursivas e as práticas de letramento envolvidas nessa área, além de analisar uma seção dos Parâmetros Curriculares Nacionais (PCN). Demonstra que eventos e práticas de letramento relativos à formação do professor devem ser analisados de maneira mais ampla do que as práticas de linguagem em sala de aula.

No décimo artigo - "Metáforas sob a lupa da Análise de Discurso Crítica" -, a organizadora desta coletânea examina alguns aspectos metafóricos patentes nos discursos de adolescentes mexicanos e brasileiros sobre o tema poluição. E conclui afirmando que as metáforas ultrapassaram os limites do meio ambiente e alcançaram novas formas de semioses associadas a momentos não-discursivos diferentes na atualidade.

No próximo artigo, "Representações da mulher na política brasileira: Análise de Discurso Crítica de registros na mídia", a professora da Unicamp e da Pontifícia Universidade Católica (PUC) de Campinas Astrid Nilsson Sgarbieri identifica aspectos ideológicos no discurso da imprensa sobre a mulher na mídia mudou, porque a sociedade brasileira mudou, já que as mulheres representam 40,3\% da força de trabalho.

A última parte "4a Parte - Veredas da Ideologia no Discurso" agrega 3 artigos, sendo 2 de doutorandas e 1 de jornalista mestre em comunicação, o que explicita, mais uma vez, o caráter múltiplo desta coletânea.

No décimo segundo artigo da coletânea - "Representação de atores sociais na cobertura brasileira da invasão do Iraque" -, a doutoranda na UnB 
Viviane C. Vieira Sebba Ramalho apresenta uma parte da análise realizada em sua dissertação em que investigou o discurso da mídia impressa brasileira sobre a invasão anglo-saxônica no Iraque em 2003. Enfoca a representação de atores sociais e os resultados indicam a reprodução do discurso ideológico proveniente dos EUA que desqualificou iraquianos e muçulmanos.

Em "Discurso jornalístico on-line: integração narrativa", a jornalista Francilaine Munhoz de Moraes aborda o jornalismo on-line e busca aprofundar as integrações e referências existentes entre a comunicação e a lingüística, em apresentação parcial da pesquisa de mestrado. Afirma, por fim, que é difícil antever os limites ideológicos do que ocorre nessa nova modalidade de comunicação.

No último artigo da coletânea - "O significado representacional no cordel Meninos de rua" -, a também doutoranda Viviane de Melo Resende analisa um cordel intitulado Meninos de rua que aborda não só a situação das crianças de rua mas também naturaliza o discurso político neoliberal, com foco no significado representacional de aspectos do mundo. A conclusão aponta para a importância do discurso na luta hegemônica.

Esta coletânea abriga a diversidade de estudos desenvolvidos hoje no Brasil na ciência lingüística: trata de questões ligadas à atividade textual-discursiva, da formação da língua portuguesa e suas relações com as línguas indígenas, dos processos sintáticos em construções específicas, na perspectiva gerativista, e da análise de discurso crítica no âmbito do ensino, da ideologia e do jornalismo. E esse é seu grande mérito: trazer o Lobato respeitoso e curioso à tona, da mesma maneira como a professora Lúcia sempre fez em suas aulas e na sua trajetória profissional. 